\title{
A estética contemporânea: nova poética, novo olhar ${ }^{1}$ \\ Cid Ottoni Bylaardt ${ }^{2}$
}

Considerando inicialmente que Modernismo e Pós-Modernismo não admitem limites precisos, propomos neste ensaio levantar indícios de que a arte pós-moderna exige - e propõe - um novo olhar, menos consistente e determinado, embora - ou por isso mesmo - mais rico. A propósito, a questão da indelimitação temporal talvez nos indique um traço importante da estética pós-moderna, que é o questionamento da própria noção de História (com inicial maiúscula) e de sua condição de discurso sequencial, teleológico, integrante de um grande metadiscurso filosóficometafísico totalizador e universalizante, para cuja falência nosso tempo parece apontar, malgrado sua tenaz resistência.

Tomemos como ponto de partida a ideia de metafísica ocidental, entendida como um conjunto de saberes tidos pela tradição iluminista como inquestionáveis e autodemonstráveis, saberes baseados numa lógica dialética, portanto binária. Um dos primeiros a colocar em questionamento esses saberes foi Friedrich Nietzsche, ao final do século XIX, e, entre os detratores da metafísica ocidental, ele é certamente o mais feroz.

O marxismo também confrontou o pensamento iluminista naquilo que ele carrega de favorecimento às elites. A partir de Karl Marx e Friedrich Engels, esse pensamento se desdobrou em várias facetas e possibilidades, e continua vivo e atuante, sempre tendo em mira a emancipação do ser humano e a eliminação da sociedade de classes. Citemos alguns: Habermas, com sua razão comunicativa, em oposição à razão instrumental; Marshall Bermann, com a reivindicação da volta ao espírito do racionalismo do século XIX para que se criem as condições para a revolução em uma visão clássica da modernidade; Perry Anderson, com sua proposta de exterminação da cultura "modernista", que enterra o velho e possibilita o nascimento do novo, tendo em vista a criação de uma comunidade de iguais; Frederic Jameson, com sua defesa de uma arte política cuja ação se desenvolva no "espaço mundial do capital multinacional", e busque uma nova forma de representá-lo, o que o pensador chama de "estética do mapeamento cognitivo".

\footnotetext{
${ }^{1}$ Aos meus alunos de Literatura Brasileira IV, que me ajudaram a escrever este texto e não sabem.

${ }^{2}$ Professor de Literatura Brasileira da Universidade Federal do Ceará, Fortaleza, Brasil. Bolsista da Capes com projeto de pesquisa intitulado "Esvaziamento da História na Literatura Contemporânea". E-mail: cidobyl@ig.com.br
} 


\section{Cid Ottoni Bylaardt}

Opondo-se à visão marxista, Jean-François Lyotard, em seu livro $L a$ condition postmoderne, critica o pensamento de tendência habermasiana, estabelecendo limites entre o moderno e o pós-moderno. Do lado do Modernismo estariam as metanarrativas, ou quaisquer discursos que pretendem legitimar o saber que defendem, como a dialética do espírito, a hermenêutica do sentido, a emancipação do sujeito racional ou trabalhador, a criação da riqueza; na dispersão pós-moderna, predomina a incredulidade quanto à possibilidade de emancipação filosófica ou política, o desmascaramento da pretensão de legitimidade da ciência.

Outros pensadores, antes e depois de Lyotard, confirmam essas tendências à desconfiança na metafísica ocidental. Entre eles, contam-se os "pós-estruturalistas" e "descontrutores". Incluem-se aí Jacques Derrida, Michel Foucault, Gilles Deleuze e Roland Barthes. Foucault denunciou a razão como forma de domínio, e, na abordagem literária, defendeu a ideia de que ela é estranha à história, de que "sua dispersão não se deve à sucessão do tempo, nem à correria noturna, mas à explosão, ao fulgor, à tempestade imóvel do meio-dia" (Machado, 2000, p. 174); Deleuze reviu o pensamento dialético a partir de Nietzsche, concentrando-se na diferença e no devir, e denominando os sistemas discursivos de raiz, radícula e rizoma, associando este último ao discurso pós-moderno; Roland Barthes levanta questões como a morte do autor, o desdobramento da obra em texto, o scriptible que não quer ser mais apenas lisible; Bauman opôs em suas inquietações o modernismo sólido ao modernismo líquido; Giorgio Agamben discute a frágil determinação da forma emblemática na cultura ocidental. Esse pensamento pós-estruturalista como um todo tem em seu bojo, de maneira geral, o questionamento do discurso metafísico ocidental, com seus pressupostos idealistas, binários, logo-etnocêntricos. E a história comparece nessas formulações como um saber linguístico linear, contínuo, teleológico.

Para os críticos pós-estruturalistas, portanto, a história é questionada em seu caráter teleológico, ou seja, não se orienta para um fim totalizador, para um ponto de chegada dos esforços do ser humano, conforme concebido racionalmente pela tradição metafísica. $O$ presente deixa, assim, de ser o lugar privilegiado no tempo, para se tomar o espaço de produção do conhecimento, que engloba os diversos discursos e formas de poder de determinada época.

A arte e a escritura não poderiam passar ao largo de tanta agitação discursiva e cultural. Os sistemas se desestabilizam, os discursos se colocam sob suspeita. No mínimo, podemos afirmar que a literatura contemporânea recusa deixar-se definir pelos meios críticos tradicionais, com suas 
noções de gênero, unidade, construção, e demais relações extraliterárias. Talvez um dos sintomas dessa recusa esteja na própria função simbólica, uma vez que o símbolo parece já não se deixar apreender de uma forma mais consistente, mais determinada.

Essa expansão do signo, essa dispersão do símbolo conduz à ideia de infinito, sustentada por Blanchot em relação à criação literária. $O$ fato de $o$ escritor possuir "apenas" o infinito faz com que as delimitações organizadoras deixem de funcionar, tornando a literatura algo absolutamente imprevisível. Assim, a abordagem da obra literária sofre necessariamente uma mudança de paradigma, que deverá conduzir inevitavelmente ao estranhamento, após tantas rupturas, desconstruções, transgressões aos modelos, questionamentos das práticas artísticas. Nas artes em geral, a revolução no conceito de objeto de arte, a supressão dos limites entre ficção e realidade, a arte multimídia, as instalações de movimentos e durações efêmeros, a utilização do corpo como objeto artístico, o alargamento do próprio conceito de arte e não arte contribuem para o efeito de estranhamento.

Uma ressalva importante que se deve fazer em relação ao Pós-Modernismo é a impossibilidade de se estabelecerem limites precisos entre ele e o Modernismo, por mais que tentemos traçar algumas linhas gerais de distinção. Não se pode esquecer que todos os eventos intelectuais retrorrelacionados situam-se num contexto de Pré-Modernismo ou Modernismo; portanto, quando se fala em desconstrução do moderno para se erigir o pós-moderno, é preciso não cair no risco de atribuir ao Modernismo uma matéria sólida e homogênea que torne possível o estabelecimento de antíteses e antagonismos que caracterizem a estética pós-moderna. Assim, os traços que apresentaremos aqui como característicos do Pós-modernismo situam-se numa perspectiva de desdobramento, intensificação e diálogo com os similares modernistas.

Considerando ainda essas transformações, na literatura brasileira, não se podem esquecer as diversas tentativas de fragmentação e até de eliminação do verso a partir dos anos cinquenta do século XX. Surgem então propostas as mais diversas, como o concretismo, o neoconcretismo, o poema-processo, os popcretos, a poesia-práxis, com seu caráter intersemiótico, multiassociativo. Após a década de 1980, a cibercultura propiciou também o aparecimento da escrita holográfica, do videoclipe, da poesiahipertextual, do poema-fractal, da poesia intersignos etc. Todas elas têm em comum a ânsia de libertar a poesia da tirania da página, do dirigismo infradestro.

A partir daqui, os poetas críticos vão falar e, com eles, vamos esboçar os traços de um novo olhar, um olhar muitas vezes estranho, errante, in- 
determinado, mas bastante mais rico de possibilidades e de aventuras. São todos poetas brasileiros dessa incrível nova poesia começante, fundante, contemporânea, pós-moderna, embora de um pós-moderno que ainda não queira ser visto como uma ruptura definitiva com o moderno, mas que intensifica alguns de seus traços, principalmente aqueles ligados a uma busca de algo ainda não declarado, e parece desprezar outros, relacionados a um projeto, a um caminho preestabelecido. Em seu livro Cultura pós-moderna, Steven Connor sugere que "A narrativa do declínio ou substituição do Modernismo é talvez menos clara, mas não menos abrangente, nos estudos literários" (2004, p. 87). E fornece uma possível razão para tal quadro: a ausência de instituições ou movimentos que irradiem tendências ou normas críticas e estéticas para a literatura, diferentemente do que ocorre na arquitetura e nas artes plásticas. Pensando na literatura brasileira, e especificamente na poesia, não se podem encontrar nas últimas décadas manifestações duradouras que tenham apontado caminhos mais ou menos consistentes na produção literária. O que se vê é uma liberdade sem precedentes na criação, o que não raro provoca a perplexidade do próprio artista em relação ao que fazer com tanta independência.

Nosso olhar de inquietação se inicia com Adélia Prado:

Antes do nome

Não me importa a palavra, esta corriqueira.

Quero é o esplêndido caos de onde emerge a sintaxe, os sítios escuros onde nasce o "de", o "aliás",

o "o", o "porém" e o "que", esta incompreensível

muleta que me apoia.

Quem entender a linguagem entende Deus

cujo Filho é Verbo. Morre quem entender.

A palavra é disfarce de uma coisa mais grave, surda-muda,

foi inventada para ser calada.

Em momentos de graça, infrequentíssimos,

se poderá apanhá-la: um peixe vivo com a mão.

Puro susto e terror. (Prado, 1993, p. 22)

A voz poética recusa as determinações da palavra, deseja-a "antes do nome", anterior ao ato de nomear, que a torna corriqueira pelo costume surrado de se colar o significado ao significante em busca de segurança e repouso. O que ela busca nessa linguagem poética é o "esplêndido caos" da palavra em estado de poesia, os "sítios escuros" que fundam um novo reino, secundados por essa "incompreensível muleta", em que a errância e a determinação dos significantes e das relações entre eles tornam a linguagem poética algo surpreendente, inesperado. A poesia é da ordem 
do divino, não foi feita para o desenlace e a compreensão confortável. Quem vê Deus morre, morre quem entender a poesia. Morre e mata-a quem pretender carregar a chave que se encaixa na fechadura. Temos aí o oráculo, direções que se apontam, mas que não revelam o enigma oculto, e mesmo que se revele uma ponta de enigma, há todo um rastro que o envolve e que não é da ordem da compreensão. Em seu ensaio "A literatura e o direito à morte", Maurice Blanchot diz algo que ressoa nesses versos de Adélia. Citando a Bíblia, ele afirma que quem vê Deus morre. Ver e compreender ligam-se à morte, uma vez que tais atos pressupõem o desenlace, a conclusão. Na linguagem usual, há a morte do objeto, cujo lugar a palavra ocupou: essa é a morte que garante a vida da palavra, e a palavra é a vida que garante a morte do objeto e se mantém nela, é o preço que pagamos pela paz, pela garantia da compreensão. Na literatura, algo ocorre que incomoda, que inquieta, que fascina nessa busca do momento que a antecede: é o susto e o terror de quem apanha o peixe-palavra. Esse divino peixe de Adélia Prado parece estabelecer um estranho diálogo com a sublime flor blanchotiana, que ressoa a flor ausente de Mallarmé:

Eu digo uma flor! Mas, na ausência em que a cito, pelo esquecimento a que relego a imagem que ela me dá, no fundo dessa palavra pesada, surgindo ela mesma como uma coisa desconhecida, convoco apaixonadamente a obscuridade dessa flor, esse perfume que me invade e que não respiro, essa poeira que me impregna, mas que não vejo, essa cor que é vestígio e não luz³. (Blanchot, 2003, p. 316, tradução nossa)

Assim como a palavra poética de Adélia Prado foi inventada para ser calada, a literatura para Maurice Blanchot se faz da ausência do objeto, transformando-o em uma imagem fundamentalmente passiva, calada, ausente do ato de reconhecimento, que se aparta do objeto assim como os sons da música se destacam do instrumento que o produz, conforme diz Levinas em "La réalité et son ombre".

Sabe-se que a recusa de atribuir um caráter destinal à linguagem poética não é propriamente pós-moderna. A tradição moderna formula-a e trabalha-a sob diversas perspectivas, e o que parecia não apresentar uma saída estética coerente e, assim, sucumbir diante da própria impossibilidade, adquire nova força na poesia contemporânea e sustenta um olhar

\footnotetext{
${ }^{3}$ No original: “Je dis une fleur! Mais, dans l'absence où je la cite, par l'oubli où je relègue l'image qu'elle me donne, au fond de cet mot lourd, surgissant lui-même comme une chose inconnue, je convoque passionnément l'obscurité de cette fleur, ce parfum qui me traverse et que je ne respire pas, cette poussière qui m'imprègne mais que je ne vois pas, cette couleur qui est trace et non lumière”.
} 
que parecia destinado a se perder. Esse "novo olhar", portanto, se faz da revitalização de uma reação ensaiada pelo código moderno.

O "Elefante", de Chico Alvim, retoma essa ideia do desconhecer, de que o texto literário não pode mais carregar o peso da consciência, de ter que mediar ou conter a cultura.

\section{Elefante}

$\mathrm{O}$ ar de tua carne, ar escuro anoitece pedra e vento.

Corre o enorme dentro de teu corpo

o ar externo

de céus atropelados. O firmamento, incêndio de pilastras,

não está fora - rui por dentro.

Reverbera no escudo o brilho baço

do túrgido aríete

com que distância e tempo enfureces.

Teu pisar macio, dançarino, enobrece os ventres frios, femininos.

A tua volta tudo canta.

Tudo desconhece. (Alvim, 2000, p. 69)

O poema retoma experimentações caras à busca de possibilidades empreendida pela estética modernista: o fato de que o texto poético é feito de obscuridade, que o poema não dá frutos, não produz verdades, não se faz de saber. Todavia, por mais que evoque a destruição dadaísta e o delírio surreal, bem como, de uma maneira geral, as contestações modernistas, a proposta poética de Alvim parece não partir de um ato faccioso ou subversivo, mas de uma constatação silenciosa de que a poesia não pode sustentar-se em noções ligadas à estabilidade de tempo, de espaço, de signos, ou à harmonia de formas. Se as vanguardas do início do século XX agitaram a estética tradicional com sua rebeldia, a poética contemporânea parece refletir profundamente sobre esses ganhos - ou perdas.

Essa poesia é feita de uma substância estranha, aérea, que obscurece tanto o que é sólido quanto o que se dispersa, desfazendo os limites normalmente atribuídos a fenômenos antitéticos. Sua matéria é a desmesura, a deformação da convivência da palavra com o mundo, as ruínas do exterior que se erguem deformadas no infinito firmamento da palavra que subverte tempo e espaço, a inconsistência de suas pilastras - ineficazes 
tanto como decoração quanto como abonação. Suas estruturas de sustentação estão destruídas, os símbolos importados do exterior pouco guardam de sua potência cultural, de seu abrigo das verdades do ser humano, que perdem a possibilidade de se situarem, uma vez que se indefinem as próprias noções de tempo e espaço. O "túrgido aríete", inchado de tanto saber, faz provocações à herança iluminista enquanto se protege em seu amparo. Em contradição com o traço que normalmente uma lógica racionalista atribui ao andar do elefante, temos aqui um "pisar macio, dançarino", enquanto os dois versos seguintes, por mais herméticos que possam parecer, parecem ressoar tanto a condição de "cooler" que Ihab Hassan atribui ao Pós-Modernismo em relação ao Modernismo compromissado e combatente (1982, p. 267), quanto a noção de devir-mulher atribuída à literatura por Gilles Deleuze em seu texto "A literatura e a vida", em que o autor vislumbra no texto literário um desvio da ordem e da dominação configuradas na figura do sujeito masculino: "O devir não vai no sentido inverso, e não entramos num devir-Homem, uma vez que o homem se apresenta como uma forma de expressão dominante que pretende imporse a toda matéria" (1997, p. 11). E complementa: "A vergonha de ser um homem, existe uma melhor razão para escrever?" (id., ibid.).

Manoel de Barros também é um poeta que dialoga obsessivamente com a palavra, em busca de seu estado original, e essa busca do desconhecer o aproxima do universo poético de Adélia Prado e Chico Alvim. O "tudo desconhece", de Alvim, dialoga com o "Antes do nome", de Adélia, que dialoga com as "coisas todas inominadas", de Manoel de Barros:

Por viver muitos anos dentro do mato

moda ave

O menino pegou um olhar de pássaro -

Contraiu visão fontana.

Por forma que ele enxergava as coisas

por igual

como os pássaros enxergam.

As coisas todas inominadas.

Água não era ainda a palavra água.

Pedra não era ainda a palavra pedra.

E tal.

As palavras eram livres de gramáticas e podiam ficar em qualquer posição.

Por forma que o menino podia inaugurar.

Podia dar às pedras costumes de flor.

Podia dar ao canto formato de sol. 
Cid Ottoni Bylaardt

E, se quisesse caber em uma abelha, era

só abrir a palavra abelha e entrar dentro

dela.

Como se fosse infância da língua. (Barros, 2007, p. 11)

O poeta reivindica a expressão poética bruta, em sua condição mais original, mais essencial possível, o signo em seu sentido não racional. $O$ conhecimento reduz, limita a espontaneidade da criação artística. O poema deve mostrar-se em sua nudez, próximo ao seu desconhecido ancestral, buscando a linguagem em sua pureza, desprovida de acúmulos históricos, que demanda um puro olhar infantil, um menino-poeta que possa lidar espontaneamente com as noções de liberdade, inconformidade, fundação de sentidos. Não se pode aqui deixar de pensar na ideia heideggeriana de instauração da verdade pela poesia: "instaurar como oferecer, instaurar como fundar e instaurar como começar" (Heidegger, 2008, p. 60). E essa instauração proposta por Heidegger passa por um tipo de saber não habitual, que ele chama salvaguarda, "a sóbria persistência no abismo de intranquilidade da verdade que acontece na obra” (id., p. 54).

Novamente são propostas ligadas de alguma forma a algo que se mexia na linguagem modernista. $\mathrm{O}$ que temos, assim, não é propriamente a invenção de um olhar, mas a apropriação e a intensificação de certas tendências modernistas pelos poetas contemporâneos. Heidegger certamente não escreveu A origem da obra de arte nos anos 1930 pensando no Pós-Modernismo.

Giorgio Agamben, um pensador que se pode chamar pós-heideggeriano, comprometido com esse olhar contemporâneo, e com as vicissitudes da linguagem, fala do idioma da poesia em seu ensaio "Ideia do único" (1999, p. 39). Segundo ele, enquanto o ser apenas compartilha a língua materna, a língua comum, que divide com os demais, ele participa de um sistema. No momento em que defronta a palavra única, fora do código habitual, é inevitável tomar partido, ou não se pode ser poeta. E esta língua não tem uma destinação, essa língua não tem identidade, porque o poeta se coloca diante do vazio das palavras. Ele é então uma criança ante o que se expõe a ela. É o infante, do latim infans, antis, o que não fala, e, portanto, não tem o que dizer dela e sobre ela, por mais que ela acene com a promessa de produzir um sentido, de estabelecer um destino, sustentada em sua gramática, em sua tradição. O poeta é, então, esse infante que se coloca diante dessa vanidade, desse oco, desse vazio, mas não sabe como preenchê-lo, talvez não saiba nunca: o poeta é o menino "moda ave" do Manoel de Barros. Daí nasce a poesia. 
Augusto de Campos, na linha concretista, aposta na explosão de formas e cores:

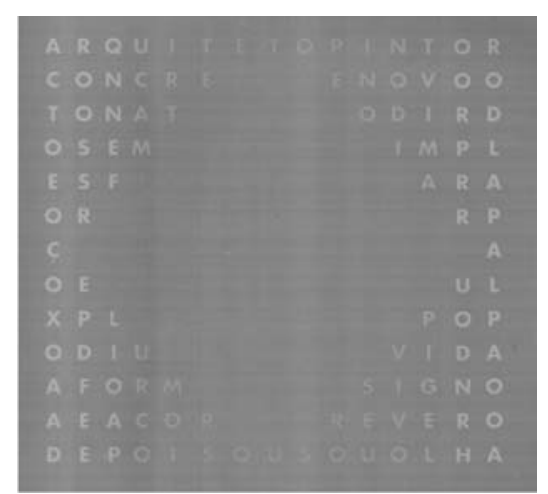

Figura 1: Poema do livro Não poemas, de Augusto de Campos (2003, p. 75)

O significante, em vez de ser utilizado como instrumento para a veiculação de um sentido, constitui-se no próprio sentido. A alteração das convenções e da forma que se espera que a palavra tenha atesta que esta não precisa representar, mas apenas ser, para provocar o efeito poético. A forma poética, assim, busca outras possibilidades, e por mais que pareça simétrica, provoca confusão. $\mathrm{O}$ artista não se conforma mais às concepções do que se considera belo em arte. Ele tem necessidade de reinventar a forma a todo instante, propondo sempre configurações inéditas ao objeto artístico. Chama a atenção a maneira curiosa como o significante se coloca no quadrado, numa ordem que pode sugerir acabamento, mas que só retém os significados sem apontar para uma saída, ou para um desfecho, na oscilação entre o explodir e o implodir do signo, e esse abalo do signo não pode deixar de remeter à ideia de superação de um saber estabelecido. Formalmente, o concretismo é uma proposta de desconstrução formal - e reinvenção de formas - também como busca de novas maneiras de dizer o que o Modernismo também já havia dito. Nesse sentido, pode-se dizer que o Concretismo tem um pé no Pós-Modernismo, evidenciando uma nova maneira de olhar o que muito já se olhou. É oportuno lembrar aqui que "olhar" não se refere apenas a uma atitude de recepção, mas principalmente um olhar de criação, de invenção, de inovação.

Paulo Leminski manifesta seu assombro diante da palavra poética, suas dúvidas e descrenças nesse beco sem saída que é a linguagem da 
Cid Ottoni Bylaardt

poesia. Embora sem ter o que dizer, o artista é atraído irresistivelmente pela obra por fazer, e o poeta declara seu espanto diante da criação:

Estupor

esse súbito não ter

esse estúpido querer

que leva a duvidar

quando eu devia crer

esse sentir-se cair

quando não existe lugar

aonde se possa ir

esse pegar ou largar

essa poesia vulgar

que não me deixa mentir. (Leminski, 2000, p. 14)

O texto encena os dilemas do poeta diante da criação, seu embate com o fazer poético, sua angústia diante do poema que surge. A verdade literária não se revela, não aponta seus caminhos, oscila sempre entre dizer e não dizer. A linguagem poética se tece mais nas dúvidas do que nas crenças; os caminhos, portanto, não estão definidos, as saídas, ou desfechos, ou conclusões não se oferecem ao poeta, o poeta é a própria poesia. Novamente, essa angústia da criação revive momentos do Modernismo que readquiriram força para se firmarem como um olhar contemporâneo. Esses momentos nos levam a "Procura da poesia" e "Máquina do mundo", de Drummond, e a "Acidente" de Henriqueta Lisboa.

A ideia leminskiana de que "não existe lugar aonde se possa $\mathrm{ir}^{\text {" faz }}$ lembrar um curioso clip-poema de Augusto de Campos, "Sem saída", que se apresenta numa forma que pode até ter sido imaginada pelos poetas modernistas, mas que só os recursos contemporâneos - recursos técnicos, propriamente - permitem sua consecução, tornando-o, nessa perspectiva, de todos os exemplos apresentados aqui, o mais Pós-Moderno. Assim, a busca de saída para o que parece sem saída passa também por uma revolução formal, suportada pela época contemporânea, que possibilita novas expressões da sensibilidade do poeta. O poema só pode ser lido eletronicamente ${ }^{4}$. O fundo onde se dá a performance do artefato é um quadrado negro, onde aparecem inicialmente superpostos e em direções caóticas sete versos como pode ser visto na figura 2:

\footnotetext{
${ }^{4}$ Disponível em CD ou na internet, no seguinte sítio: <http://www2.uol.com.br/augustodecampos/semsaida.htm>.
} 
A estrada é muito comprida

O caminho é sem saída

Curvas enganam o olhar

Não posso ir mais adiante

Não posso voltar atrás

Levei toda a minha vida

Nunca saí do lugar

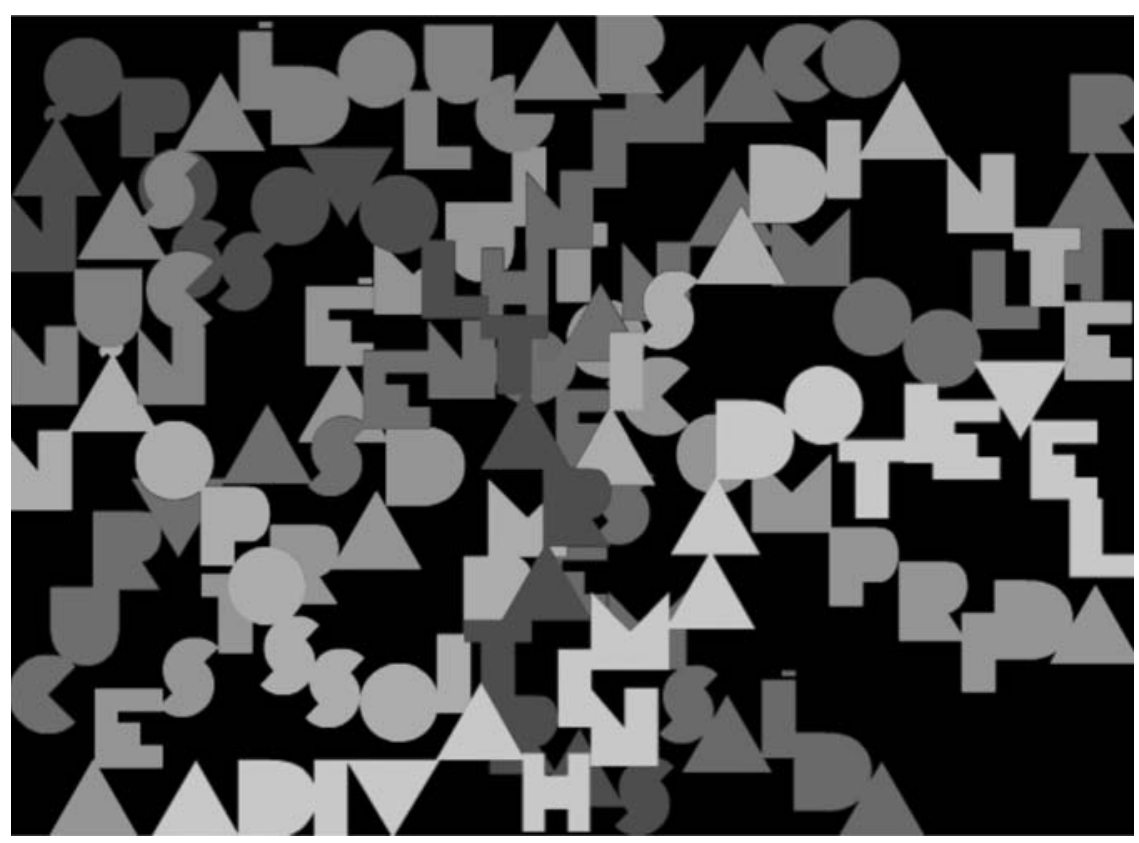

Figura 2: "Sem saída", Augusto de Campos. Disponível em:

<http://www2.uol.com.br/augustodecampos/semsaida.htm>.

Cada um dos versos aparece com uma cor berrante: verde, vermelho, rosa-choque, azul-piscina, roxo, amarelo e laranja, respectivamente. Ao clique do mouse, o quadro se torna todo negro novamente e, a um novo clique, aparece o primeiro verso, à medida que se arrasta o cursor com o mouse. Note-se que o verso vai aparecendo, mas não seguindo o cursor, e sim em direções divergentes do traçado que se dá ao apontador. E assim por diante, a cada clique e a cada arrasto, aparece novo verso e nova cor. No verso final, a expressão "do lugar" fica agarrada à mãozinha, e o leitor só se desvencilha dela com um novo clique. Aí aparecem novamente todos os versos superpostos e sendo falados por vozes masculinas também superpostas, como uma estranha récita coral de orações polifônicas. 


\section{Cid Ottoni Bylaardt}

O efeito é muito bonito, e o poema é bastante instigante. O título é emblemático dessa atitude contemporânea, dessa impossibilidade de sair do lugar, ou seja, de não perceber na lógica racional nenhum suporte para a fixação de verdades, que ficam dando voltas num quadrado negro, como os signos em rotação de Octavio Paz, sem saber direito o que buscam e sem possibilidade de encontrar respostas.

O desdobramento dessa misologia é acentuado pelo poema de Arnaldo Antunes, feroz contestador da linguagem da razão, da metafísica iluminista:

Eu apresento a página branca.

Contra:

Burocratas travestidos de poetas

Sem-graças travestidos de sérios

Anões travestidos de crianças

Complacentes travestidos de justos

Jingles travestidos de rock

Estórias travestidas de cinema

Chatos travestidos de coitados

Passivos travestidos de pacatos

Medo travestido de senso

Censores travestidos de sensores

Palavras travestidas de sentido

Palavras caladas travestidas de silêncio

Obscuros travestidos de complexos

Bois travestidos de touros

Fraquezas travestidas de virtudes

Bagaços travestidos de polpa

Bagos travestidos de cérebros

Celas travestidas de lares

Paisanas travestidos de drogados

Lobos travestidos de cordeiros

Pedantes travestidos de cultos

Egos travestidos de eros

Lerdos travestidos de zen

Burrice travestida de citações

água travestida de chuva

aquário travestido de tevê

água travestida de vinho

água solta apagando o afago do fogo

água mole sem pedra dura 
água parada onde estagnam os impulsos

água que turva as lentes e enferruja as lâminas

água morna do bom gosto, do bom senso e das boas intenções insípida, amorfa, inodora, incolor

água que o comerciante esperto coloca na garrafa para diluir o whisky

água onde não há seca

água onde não há sede

água em abundância

água em excesso

água em palavras.

Eu apresento a página branca.

A árvore sem sementes.

$O$ vidro sem nada na frente.

Contra a água. (Antunes, 1993, p. 16)

O poema ataca inflexivelmente as formas de discurso que têm a pretensão de organizar a sociedade dos humanos: a poesia convencional, o cristianismo, a seriedade da metafísica, os discursos da boa intenção, do bom senso, do bom gosto, do politicamente correto, do socialmente valorizado etc. $\mathrm{O}$ enunciado apresenta a página branca, não contaminada do racionalismo iluminista e denuncia essa água do palavrório que organiza os sistemas. Tudo é aparência, mentira, engodo. As frases que representam as execrações do poeta têm sempre a mesma estrutura: o primeiro elemento do enunciado é sempre algo que representa a essência daquilo que é criticado, e o segundo elemento é o resultado da transformação que gera uma aparência valorizada pelo sistema social. O que se vê realmente não passa de enganação, engodo, verdades depreciáveis travestidas para parecerem positivas aos olhos que apreciam o espetáculo da mídia iluminista.

Formalmente, o poema apresenta também um novo olhar, desta vez para a cultura contemporânea, e de uma maneira contemporânea. Depois de propor apresentar a página branca, o locutor apresenta uma verdadeira litania de recusas e desconstruções, sempre presididas pela expressão "travestido/a/os/as de", que carrega em nossos dias um peso depreciativo, ofensivo à decência. Há então uma inversão: o que deveria ser decente é acusado de indecente, e o poeta então denuncia mediante o verbo travestir algo que se esconde por trás da linguagem da ordem, edulcoradora.

Apresentar a página em branco, portanto, é recusar as saídas convencionais, é enfrentar a própria falta de saídas, é buscar possibilidades em saberes não habituais. Nessa página em branco serão escritos os poemas que perderam as referências, que se constroem dos não sentidos das pa- 


\section{Cid Ottoni Bylaardt}

lavras, além da linguagem comunicativa, em busca de sua independência daquilo que os tornou possíveis. Seu criador só pode produzir a poesia repleta de vazio, feita da impossibilidade de dizer, da insuficiência das palavras, mas ao mesmo tempo feita de uma linguagem que não pode não falar. A poesia está lá, mas as palavras não querem - ou não podem - escrever, afirmar, dizer o que deve ser dito, ou o que se espera que seja dito.

Como o poema não promete mais um caminho a seguir, a veiculação de um saber que o complete, ele permanece num estado de permanente inacabamento, em seu polimorfismo, como sugere Waly Salomão:

Por hoje é só.

OBRA parida com a mesma incessante INCOMPLETUDE.

Sempre tendente a ser outra coisa. Carente de ser

mais.

Sob o signo do ou.

O U.

Transbordar, pintar e bordar, romper as amarras,

soltar-se das margens, desbordar, ultrapassar as bordas,

transmudar-se, não restar só sendo si-mesmo, virar ou-tros seres.

Móbil.

OBRAS DA INCOMPLETUDE.

De qualquer modo intenso deixar algumas

BROCAS no muro do mundo: esta é uma

arquetípica ficção-consolo dum intempestivo.

$$
\mathrm{O} \mathrm{U}
$$

Pois que ou-tra alternativa há senão convocar as

tropas do exército de virtualidades do duo vocálico

O U?

Cobra que muda de pele. E se embrulha em duas vogais para fazer a travessia do rio a vau. Vadear.

$$
\mathrm{O} \mathrm{U}
$$

Sob o signo de PROTEU vencerás.

Quem é esse Proteu intrometido texto a dentro pra vadiar?

\section{BANCO DE DADOS:}

Proteu: mitologia grega: deus marinho recebera de seu pai, Posêidon, o dom da profecia e a capacidade de se metamorfosear, o poder de variar de forma, a seu bel prazer. 
Sob o signo de PROTEU vencerás.

Por cima do cotidiano estéril

de horrível fixidez

careta demais

Que máximo prazer, ser ou

tros constantemente.

... Passageiros ... nossa próxima estação ...

LER COM OLHO-FÓSSIL

OU

LER COM OLHO-MÍSSIL

(Salomão, 2000.)

A partir da própria forma, a veicular uma sensação de dispersão, de palavras que permanecem em fragmentos, inacabadas como a própria proposta de criação, o poema de Salomão é o que nunca está realmente, o que nunca chega, mas está sempre em transformação, sempre "sob o signo de PROTEU", a obra de arte é um estranho ser em permanente metamorfose. A poesia não recusa nada, mas não aceita prender-se a tendências estabelecidas, em sua condição de ser polimorfo, escorregadio. $\mathrm{O}$ poema parece ter consciência de sua própria precariedade, de seu inacabamento, mas sugere alternativas aqui e ali.

Sebastião Uchoa Leite estabelece uma comparação bastante oportuna entre a poesia contemporânea e a pós-moderníssima informática:

Digitações

A poética é uma máquina

Há um código central

Em que se digita ANULA

É a máquina do nada

Que anda ao contrário

Da sua meta

A repetição é a morte

Noutro código lateral

Digita-se ENTRA

E os cupins invadem o quarto. (Leite, 1991, p. 21)

O poema recusa a atribuição de funções à poesia, rejeita a finalidade de encurtar caminhos, de resolver problemas. O texto poético é isento de objetivos, de determinações, recusando o caráter de aparato funcional, o saber de centro, invertendo e mesmo corroendo os meios tradicionais 
de expressão. Assim como a linguagem binária da informática, que aqui é sintetizada em dois de seus mais importantes comandos, DELETE e ENTER, a linguagem poética é um código. As semelhanças se esvaem aí: se a informática existe para apontar ou facilitar a consecução de metas, a linguagem poética parece correr em sentido contrário a elas, anulandoas. Se a linguagem dos computadores permite o acesso de informações que asseguram o funcionamento do sistema por suas portas laterais, a linguagem poética, por mais pós-moderna que seja, insiste em deixar entrarem os vermes que vão impedir o sistema de se sustentar, numa imagem que se aproxima do "incêndio de pilastras" no "Elefante", de Francisco Alvim.

Temos aí então alguns traços desse novo olhar da poesia contemporânea, da literatura contemporânea, que faz girar os saberes, as formas, os gêneros, os conceitos que até um certo momento nos bastavam para enquadrar o texto literário. Fica então a pergunta incômoda: o que há nesse olhar que o torna novo em relação ao código modernista? Talvez a diferença esteja na maneira como os modernos tratavam os antigos e os pós-modernos tratam o novo. No caso do modernismo, arriscamos dizer que ele preconizava uma nova ordem a que pudesse se conformar, uma nova potência a que se submetesse como condição de descartar a potência antiga. Se a descrença modernista buscava alternativas de substituição, a descrença pós-moderna parece abrigar uma tendência a não ver alternativas. Se pensarmos nos nove exemplos aqui apresentados, que representam uma parte significativa do pensamento estético contemporâneo na literatura brasileira, ou pelo menos na poesia brasileira atual, considerando como atual o final do século XX e o início do século XXI, veremos que todos eles têm em comum uma profunda descrença nos saberes da herança racional-iluminista, tanto os saberes ligados à cultura em geral quanto os saberes específicos da criação poética. Pode-se argumentar que essa descrença já vem do Modernismo, mas a maneira como ela se apresenta nos parece radicalmente diferente.

Ihab Hassan, em seu livro The dismemberment of Orpheus, propõe três modos de mudanças na arte nos últimos cem anos: as vanguardas, o moderno e o pós-moderno, tendo como ponto de sustentação a ideia de que a literatura tende ao silêncio, de Sade a Beckett, e que esse silêncio se acentua em direção ao pós-moderno. O que ele chama "literatura do silêncio" parece ser uma tendência desconstrucionista, paratática, esquiva ao significado, em oposição ao que seria o hierático, hipotático, significativo do Modernismo. As vanguardas, para ele, foram as grandes agitações que 
abalaram as artes e a cultura nas duas primeiras décadas do século XX, que assombraram a burguesia com sua anarquia, irreverência, espírito transgressor. Para Hassan, essas vanguardas tiveram sua bravura e brio iniciais substituídos por uma memória histórica; o Modernismo, entretanto, foi mais estável, hierático; o Pós-Modernismo, enfim, tende novamente à desestabilização, embora não tão explicitamente contestadora como as vanguardas haviam sido.

Admitamos que o Modernismo não tenha sido tão estável e hierático como sugere Hassan, e certamente não foi, mas, em seus desdobramentos, uma vez baixada a poeira da agitação vanguardista, ele tentou se arrumar, estabelecer uma ordem, enquanto o Pós-modernismo parece não poder ou não querer impor nenhum tipo de ordem ou estabelecer proposta, confirmando a sugerida tendência ao silêncio, que Maurice Blanchot, nas pegadas de Heidegger, foi um dos primeiros a apontar, nos anos 1940, como uma direção que a literatura estaria tomando. Voltando aos exemplos da literatura brasileira acima comentados, observamos que se a poesia não tem mais o que dizer; se ela quer passar a borracha em todo esse saber vazio que preenche a literatura, talvez tenhamos aí a grande diferença em relação às propostas modernistas: não há mais contra o que lutar, não há mais um inimigo - a burguesia, o capitalismo, a sociedade de classes - eleito como tal. O que resta é a linguagem, e essa parece ser a grande aposta da poética contemporânea - ou pelo menos de parte significativa dos poetas: não a linguagem que diz, ou que precisa dizer alguma coisa, mas uma linguagem que parece cada vez mais se desdobrar sobre si mesma no gesto indiferenciado daquele que escreve, em seu avesso obscuro e silencioso.

\section{Referências bibliográficas}

AGAMBEN, Giorgio (1999). Ideia da prosa. Trad. João Barrento. Lisboa: Cotovia.

ALVIM, Francisco (2000). Elefante. São Paulo: Companhia das Letras.

ANTUNES, Arnaldo (1993). Tudos. Rio de Janeiro: Iluminuras.

BARROS, Manoel de (2007). Poemas rupestres. 3. ed. Rio de Janeiro: Record.

BLANCHOT, Maurice (2003). La part du feu. Paris: Gallimard.

CAMPOS, Augusto (2003). NÃO poemas. São Paulo: Perspectiva.

CONNOR, Steven (2004). Cultura pós-moderna: introdução às teorias do contemporâneo. 5. ed. Trad. Adail Ubirajara Sobral e Maria Stela Gonçalves. São Paulo: Edições Loyola.

DELEUZE, Gilles (1997). Crítica e clínica. Trad. Peter Pál Pelbart. São Paulo: Editora 34. 


\section{Cid Ottoni Bylaardt}

HASSAN, Ihab (1982). The dismemberment of Orpheus. Madison: The University of Wisconsin Press.

HEIDEGGER, Martin (2008). A origem da obra de arte. Lisboa: Editora 70.

LEITE, Sebastião Uchoa (1991). A uma incógnita. São Paulo: Iluminuras.

LEMINSKI, Paulo (2000). La vie en close. São Paulo: Brasiliense.

MACHADO, Roberto (2000). Foucault, a filosofia e a literatura. Rio de Janeiro: Jorge Zahar.

PRADO, Adélia (1993). Bagagem. Sao Paulo: Editora Siciliano. (2006). O coração disparado. Rio de Janeiro, Record.

SALOMÃO, Waly (2000). Gigolô de bibelôs. Rio de Janeiro: Rocco.

Recebido em maio de 2011.

Aprovado em outubro de 2011.

\section{resumolabstract}

\section{A estética contemporânea: nova poética, novo olhar}

Cid Otoni Bylaardt

O chamado Pós-Modernismo no Brasil, como na maioria dos países do mundo ocidental, é um fenômeno multifacetado, repleto de indeterminação. Um dos aspectos desse panorama é a desconfiança das estruturas discursivas pretensamente estáveis que pareciam caracterizar a linguagem modernista, a consciência da precariedade dos fundamentos e determinações, disseminando-se então na ideia de errância, de dispersão, de insuficiência do pensamento dialético de suporte racionalista-iluminista. Essa atitude tende a produzir uma estética do estranhamento, em que a literatura parece inclinar-se a se configurar como uma atividade singular, um ato indiferenciado daquele que escreve, no avesso obscuro e silencioso da linguagem. Este texto pretende empreender uma reflexão sobre como essa dispersão de saberes, e suas relações com o poder de dizer se processam em algumas obras já canônicas da literatura brasileira contemporânea, e como essa condição parece determinar uma nova maneira de se olhar essa literatura, subvertendo os saberes, as formas, os gêneros, os conceitos que até um certo momento nos bastavam para enquadrar o texto literário.

Palavras-chave: pós-modernismo, dispersão de saberes, novo olhar

\section{The contemporary aesthetic: new poetry, new look}

Cid Otoni Bylaardt

The so-called Post-Modernism in Brazil, as in most western countries, is a multiple phenomenon, full of indetermination. One aspect of this panorama is the distrust of speech structures once considered stables that seemed to characterize the modernist language, and also the consciense of the precarious status of the groundworks and determinations, which is disseminated in the idea of scatte- 


\section{A estética contemporânea}

ring, of insuficiency of the dialectics supported by enlightenment and rationalism. This attitude tends to produce an aesthetics of unfamiliarity, in which literature is inclined to be seen as a singular activity, as an indiferentiated act achieved by the one who writes, in the obscure and silent side of language. This text intends to make a reflection on some renowned poems of the contemporary brazilian literature, and on how this condition seems to determine a new look to this literature, subverting the knowledge, the forms, the genders, the concepts that at a certain point were sufficient to explain the literary text.

Key words: post-modernism, dispersal of knowledge, new look 